\title{
Editor's Note: Special Issue on International Embedded Systems Symposium (2019)
}

(C) Springer Science+Business Media, LLC, part of Springer Nature 2021

International Journal of Parallel Programming gratefully acknowledges the editorial work of the scholars listed below on the special issue entitled "International Embedded Systems Symposium."

\section{Dr. Marcelo Gotz}

Universidade Federal do Rio Grande do Sul

\section{Dr. Achim Rettberg}

University of Applied Science Hamm/Lippstadt

Publisher's Note Springer Nature remains neutral with regard to jurisdictional claims in published maps and institutional affiliations. 